\title{
Is a cooperative approach to seaweed farming effectual? An analysis of the seaweed cluster project (SCP), Malaysia
}

\author{
Adibi M. Nor ${ }^{1} \cdot$ Tim S. Gray $^{2} \cdot$ Gary S. Caldwell $^{1} \cdot$ Selina M. Stead ${ }^{1}$
}

Received: 17 August 2016/Revised and accepted: 21 November 2016/Published online: 10 December 2016

(C) The Author(s) 2016. This article is published with open access at Springerlink.com

\begin{abstract}
Seaweed (Kappaphycus spp.) farming has been practised in Malaysia since the late 1970s following government policy incentives (training and farming inputs). However, numerous governance, economic, environmental, technological and sociocultural challenges have limited the industry from achieving its full potential. The Seaweed Cluster Project (SCP) was introduced in 2012 to address some of these challenges. We sought to evaluate the effectiveness of the SCP in delivering its central objectives of increasing seaweed production, optimising the farming area, improving seaweed quality and farming efficiency, raising farmers' income, and reducing the environmental impact of seaweed farming. Community and industry perceptions of the SCP were obtained from seven communities using a mixed-methods approach based on face-to-face semi-structured interviews, focus group discussions, household surveys, observation and secondary data. Views on the SCP outcomes were generally negative, including low take-up rates by indigenous people, poor stakeholder participation in decision-making, limited acceptance of new technologies, economic vulnerability, a complex marketing system, and low social cohesion of seaweed farming communities. Positive perceptions included recognition that the SCP confers high social status upon a community, reduces operating costs, and facilitates
\end{abstract}

Adibi M. Nor

a.md-nor@newcastle.ac.uk

1 School of Marine Science and Technology, Newcastle University, Ridley Building, Claremont Road, Newcastle upon Tyne, England NE1 7RU, UK

2 School of Geography, Politics and Sociology, Newcastle University, Newcastle upon Tyne, England NE1 7RU, UK the production of certified seaweed. The SCP's problems are linked to poor multi-level governance, weak market mechanisms and unintegrated community development. The study concludes with five recommendations to improve the SCP: promote the participation of indigenous people; legalise existing migrant farmers; strengthen local seaweed cooperative organisations; provide entrepreneurship skills to farmers; and fully integrate stakeholders into decision-making.

Keywords Aquaculture $\cdot$ Seaweed farming $\cdot$ Governance . Community $\cdot$ Policy $\cdot$ Malaysia

\section{Introduction}

Demand for carrageenan from the processed food industry has increased substantially since the 1960s (Hurtado et al. 2012), fuelling strong growth in the seaweed aquaculture sector. Kappaphycus farming expanded into Eastern Malaysia (Semporna district, Sabah) in the late 1970s (Sade et al. 2006). However, ecological problems and low seaweed pricing resulted in poor uptake from the indigenous people. Civil war in the southern Philippines precipitated the migration of Filipinos to Sabah in the 1970s and 1980s (Allerton 2014; Razali et al. 2015) where they worked in the fishing, palm oil and cocoa industries, and subsequently adopted seaweed farming. From the late 1980s, the indigenous communities began to accept seaweed farming as an alternative livelihood to fishing, having learned to farm from the Filipino community. The Sabah Fisheries Department (SFD) subsequently provided assistance to 10 local fisher families occupying 10 ha of farming space (Dalli 1988). This action prompted additional coastal communities to engage in seaweed farming. A further stimulus stemmed from strong demand from foreign processors, driving prices 
upwards from MYR 0.50 (US\$0.15) per kg in 1991 to MYR 1.70 (US\$0.51) per kg in 1996.

In 2012, the Malaysian government (through the National Seaweed Technical Committee, NSTC) introduced the Seaweed Cluster Project (SCP) into Semporna, focusing on the villages of Lok Butun and Gelam-gelam. The SCP was designed to aggregate the existing farmers under a system of cooperativeowned enterprises, managed by the farmers but controlled by the government. The goals of the SCP were to increase national production, raise farmers' income, optimise the farming area, improve farming efficiency and seaweed quality, and reduce the environmental impact of seaweed farming activities. The goals were to be met by adopting farming approaches that were new to Malaysia, specifically: the replacement of raffia tie-tie with polyethylene tie-tie; using poly-floats rather than recycled plastic bottles; switching to detachable eco-friendly longlines; use of cement anchoring systems; the supply of seedling (propagule) tying tables, wooden drying platforms, and fibreglass boats; and the establishment of the Malaysian Good Aquaculture Practises (MyGAP) certification scheme. The remaining sections in this paper explain and evaluate for the first time the SCP's attempts to meet these goals. Lessons learned have wider implications for other seaweed producing nations facing similar problems.

\section{Methods}

\section{Ethics statement}

Ethical approval for this study was obtained from the Newcastle University Ethics Committee. Additional permissions were granted by the Malaysian government (Economic Planning Unit, Prime Minister's Department).

\section{Study area}

Situated in Southeast Asia, Malaysia (population 28.3 million) comprises two non-contiguous land areas separated by the South China Sea: 'Peninsular Malaysia' bordering Thailand on the northern side and 'East Malaysia' on the northern side of Borneo. East Malaysia comprises two states, Sabah and Sarawak. Sabah has the third highest state population (3.21 million) in Malaysia, but the second lowest population density (44 people $\mathrm{km}^{-2}$ ) (DOS 2010). Sabah was the major contributor to the national Gross Domestic Product (GDP) for the agriculture sector in 2013; $16.8 \%$ of MYR 56.1 billion (US\$ 17.1 billion). At the state level, agriculture contributed $20.6 \%$ of GDP, and the fishing sector 2.4\% (DOS 2013).

Sabah was chosen as the research site as it is the only seaweed producing state in Malaysia operating at a commercial scale $(26,076 \mathrm{t}$ in 2015). Semporna (population 137,868) spans $114,477 \mathrm{ha}$, comprising the mainland and 50 islands.
Bum-bum, the second largest island in Semporna, contains $7.3 \%$ (>10,000 inhabitants) of the total Semporna population (Semporna District Office, unpublished data). Semporna comprises different ethnicities including Bajau (the largest), Bugis, Kadazan, Malay and Tausug (Suluk) (DOS 2010). With a total budget of MYR 8.03 million (US\$2.64 million) the SCP was introduced in 2012 to four areas in Sabah: three cluster groups in Semporna district (Lok Butun, Gelam-gelam and Silungun villages) and one cluster group in Tawau district (Merotai village). The current study was, by necessity, limited to the neighbouring villages of Lok Butun (population 618) and Gelam-gelam (population 1085) (Semporna District Office, unpublished data) in response to the following three factors; 1) both villages were SCP pioneers; 2) fieldwork resources prevented wider inclusion of other SCP communities; and, 3) safety concerns as a direct consequence of travel restrictions imposed in respose to conflict between insurgents and Malaysian security forces in Lahad Datu and Semporna, Sabah. Seven communities were chosen to evaluate the SCP: two SCP communities (Lok Butun and Gelam-gelam), four individual farmer communities, i.e., individual households not part of a cooperative (Sebangkat a and b, Sangaban a and $b$, Patuit $a$ and $b$ and Palang-palang), and one cooperative farming community (Mata Pahi/Melanta Kobal) (Fig. 1).

\section{Data collection}

Fieldwork began with a reconnaissance and fact-finding activity (April 2015) as an initial exploration of a seaweed farming community. Furthermore, this activity was conducted to gain awareness of community leaders, key authorities, government departments, and other stakeholders related to seaweed farming and management of the seaweed industry. The full survey (April to June, 2015) utilised four research instruments: key informant (KI) interviews, focus group discussions (FGD), household surveys (HS), and observation and secondary data. Face-to-face semi-structured interviews $(n=42)$ were conducted with 42 key informants, including government officials at local, state, and national levels; a seaweed pioneer (the first local person to introduce seaweed farming to Malaysia); seaweed buyers; carrageenan processors; community representatives; SCP leaders; and a non-governmental organisation (NGO) representative (World Wide Fund for Nature, WWF). The sample comprised 7 females and 35 males. The KI were selected using non-probability sampling through purposive sampling. The snowball method (by asking people to suggest the names of potential $\mathrm{KI}$ ) was used to identify the KI in managing the seaweed industry. The selection of KI for semi-structured face-to-face interviews and FGD was based on their expertise and decision-making roles. Three FGD were carried out with groups of seaweed farmers, processors and buyers $(n=40)$. 
Fig. 1. Map of the study area showing the locations of the seaweed communities and their nearby towns

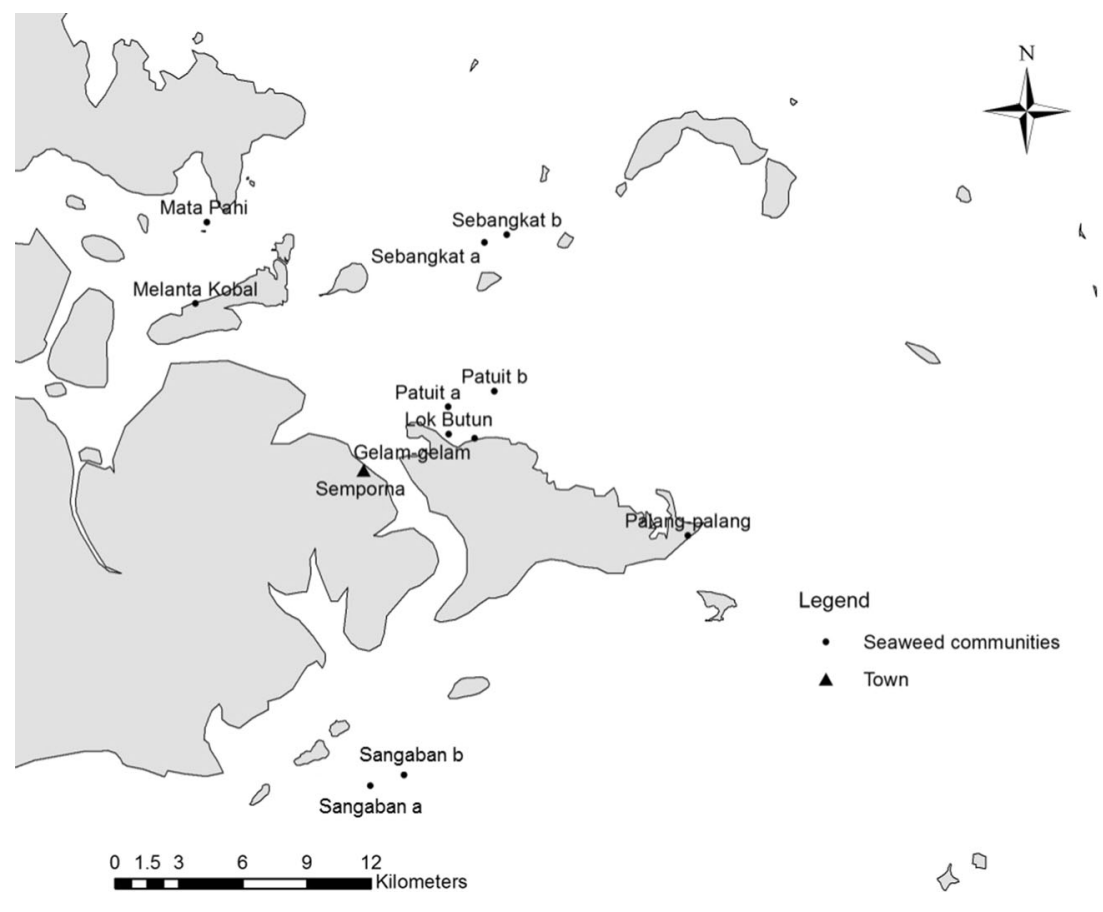

The HS were administered to 144 households in the seven study communities. The SCP participants were selected from a list of names provided by the Sabah Fisheries Department (SFD). The selection reflected the impacts of the introduction of the SCP at the household level. In total, 25 and 15 participant households were selected in Lok Butun and Gelam-gelam respectively. Using purposive sampling and a list provided by the Semporna Area Farmers' Association (SAFA), the selection represented individual farmers $(n=87)$ and cooperative members $(n=17)$. There was not a list of individual farmers, so the household heads were selected through purposive sampling due to their status as migrants. A boat was hired on a daily basis to survey these farmers. Using nonprobability sampling methods through purposive sampling, three farmer categories were selected: (1) SCP participants; (2) individual participants or migrant farmers living in stilt houses (pondohan); and (3) local cooperative members.

The KI interviewees were asked questions in face-toface in-depth interviews using questionnaires with openended questions. The survey questionnaires were developed in English, translated into 'Bahasa Melayu', and focused on the following topics: (1) farmers' demographic information, (2) household economy, (3) perceptions of community development, (4) social participation, (5) farm characteristics and farming activities, (6) material style of life, (7) perceptions of access to resources, (8) perceptions of problems encountered in seaweed farming, (9) perceptions of seaweed industry management, and (10) perceptions of the SCP. Interviewees were asked whether they agreed, disagreed or were neutral on questions related to (3) (4) (7) (8) ( 9) using a Likert-type scale (Thurstone 1928). The SCP participants were asked (10) whether or not the SCP had changed their income or production since they joined the cooperative. Using pictorial guides as part of the questionnaires, the participants were also asked to rank the eight types of assistance provided as part of the SCP in terms of usefulness and practicality.

Permission letters were sent to KI prior to interviews, and invitation letters were sent to the respondents before the FGD. All participants were contacted by telephone, email or met in person to obtain assurances of their attendance. The interviews took place at various locations including at sea, at their homes, business premises and offices, in restaurants, community halls and public library meeting rooms.

\section{Data analysis}

The selection of themes for analysis was decided using the method proposed by Ryan and Bernard (2003). The data were textual, and transcribed from an audio recorder and interview guide. The transcripts from the KI interviews, FGD, fieldwork notes, observation and HS were coded. Different codes were chosen to allow thematization of underlying patterns. Themes were analysed for connections between data, concepts and theories. Interview data were transcribed, uploaded into NVivo 11 qualitative research software (QSR International Pty Ltd.), and organised into four broad categories: governance, economic, environmental, technological and sociocultural. Survey data were 
analysed as a descriptive analysis using SPSS version 21 quantitative research software (IBM Corp.) and plotted as a principal component analysis (PCA) using Plymouth Routines in Multivariate Ecological Research (PRIMER) software (Plymouth Marine Laboratory) based on the variables and questions shown in Table 1. The assessment of social network strength and leadership followed Bodin and Crona (2008); however, in the present study PCA was incorporated to explore possible relationships between social capital, leadership and the need for government intervention.

\section{Results}

\section{Demographic composition of Semporna seaweed farmers}

The demographic composition of seaweed communities in Semporna is presented in Table 2. Although the majority of farmers were married (90\%), there was limited female participation in farming activities (less than 30\%), with women mainly assisting males in longline cleaning, seeding or drying.

Despite there being an age limit criterion to becoming an SCP beneficiary (under 50 years of age), $22.5 \%$ were older than 50 years old.

"We only selected participants below 50 years old. Moreover, priority went to unemployed youths with a family. Previously, we had some participants that were over 50. We revised the age factor because, in the seaweed certification programme (MyGAP), participants were required to undergo a medical health check-up. This resulted in elderly participants not qualifying for MyGAP. The Sabah Fisheries Department instructed us to substitute elderly participants with younger ones" (SCP Leader LB KI interview, 13 Apr 15).

On the other hand, non-SCP farmers (migrant and SAFA) had the highest proportion of farmers younger than 50 years $(80.5 \%)$, most commonly in the 30-39 age category (migrant
$=34.5 \%, \mathrm{SAFA}=52.9 \%$ ). However, a Kruskal-Wallis test showed that age was not significantly different between the seaweed communities.

All farmers were Muslim and the majority of the SCP and SAFA farmers ( 97.5 and $64.7 \%$ respectively) were Bajau, while migrant farmers - either war refugees or illegal Filipino migrants - were Suluk. The Suluks occupied most of the productive farming areas that were unoccupied by indigenous farmers, i.e., reef areas or remote islands. A KI SFD official stated that "the majority of people involved with seaweed farming are illegal immigrants." More than $45 \%$ of nonSCP farmers originated from another country, whereas $97.5 \%$ of the SCP farmers originated from the same community, with $90 \%$ having resided in the community for more than 20 years. SAFA farmers had the highest proportion of farmers $(41.2 \%)$ having lived in the area for less than five years. Most migrant farmers (68.6\%) originated from the southern Philippines, and $45.5 \%$ of SAFA farmers with less than five years residency were of Filipino extraction. As a respondent noted:

\section{"Seaweed farming is dominated by the Suluk ethnicity (originated from the Southern Philippines). I think their contribution to seaweed farming is important. Only a few indigenous people are interested in seaweed farm- ing. One of the challenges in this industry is how to increase participation amongst indigenous people (Sabahan) and how to solve issues with immigrant farmers from the Southern Philippines - i.e., legalise their existence as seaweed farmers or take over their farming sites and give them to the indigenous people" (PPK Manager KI interview, 14 Apr 15).}

The KI reported that the highest seaweed production levels were achieved by the migrant farmers and "they are the key people in this industry that provide a large proportion of the labour force" (Processor LF KI interview, 13 Apr 15).

More than $50 \%$ of farmers in all communities had obtained some level of formal education, either in Malaysia or their country of origin. Migrant farmers had a higher proportion of no formal education and only $1.2 \%$ had obtained higher education.
Table 1. Examples of the variables and questions asked to assess social network strength in seaweed communities in Semporna

\begin{tabular}{ll}
\hline Variables & Questions \\
\hline $\begin{array}{l}\text { Individualistic } \\
\text { Conflicts }\end{array}$ & Do you think people are only interested in their own welfare? \\
Intervention & Are there unresolved issues or problems between people in the community? \\
Trusting & Do you think the government should solve major problems that affect the community? \\
Harmonious & Do you think most people in the community are honest and can be trusted? \\
Accepted & Are relationships in the community generally good? \\
Leadership & Do you feel accepted as part of the community? \\
Problem solving & Do you think there are strong leaders in the community who are respected? \\
\hline
\end{tabular}


Table 2. Demographic data of seaweed communities in Semporna, taking into account gender, age, ethnicity, religion, marital status, education, extent of experience of seaweed farming, place of origin, and time living within the farming community. $\mathrm{SCP}=$ Seaweed Cluster Project, SAFA = Semporna Area Farmers' Association

\begin{tabular}{|c|c|c|c|}
\hline & Type of farmer & & \\
\hline Variables & $\operatorname{SCP}(n=40)$ & Non-SCP $(n=87)$ & SAFA $(n=17)$ \\
\hline \multicolumn{4}{|l|}{ Gender (\%) } \\
\hline Male & 77.5 & 75.9 & 70.6 \\
\hline Female & 22.5 & 24.1 & 29.4 \\
\hline \multicolumn{4}{|l|}{ Age (\%) } \\
\hline Below 50 years old & 77.5 & 80.5 & 76.5 \\
\hline Above 50 years old & 22.5 & 19.5 & 23.5 \\
\hline \multicolumn{4}{|l|}{ Ethnicity (\%) } \\
\hline Bajau & 97.5 & 5.7 & 64.7 \\
\hline Suluk & 2.5 & 77 & 5.9 \\
\hline Other & 0 & 17.2 & 29.4 \\
\hline \multicolumn{4}{|l|}{ Religion (\%) } \\
\hline Islam & 100 & 100 & 100 \\
\hline \multicolumn{4}{|l|}{ Marital status (\%) } \\
\hline Married & 90 & 92 & 100 \\
\hline Single & 2.5 & 3.4 & 0 \\
\hline Widowed & 2.5 & 4.6 & 0 \\
\hline Divorced & 5 & 0 & 0 \\
\hline \multicolumn{4}{|l|}{ Level of education (\%) } \\
\hline Higher education & 0 & 1.2 & 0 \\
\hline Secondary & 42.5 & 10.5 & 23.5 \\
\hline Primary & 37.5 & 45.3 & 52.9 \\
\hline No formal education & 20 & 43 & 23.5 \\
\hline \multicolumn{4}{|c|}{ Experience in seaweed farming (\%) } \\
\hline Less than 5 years & 10 & 16.1 & 52.9 \\
\hline $6-10$ years & 10 & 28.7 & 23.5 \\
\hline $11-15$ years & 15 & 24.1 & 0 \\
\hline $16-20$ years & 22.5 & 18.4 & 11.8 \\
\hline More than 20 years & 42.5 & 12.6 & 11.8 \\
\hline \multicolumn{4}{|l|}{ Place of origin (\%) } \\
\hline This community & 97.5 & 3.5 & 30.1 \\
\hline This island & 2.5 & 15.1 & 14.7 \\
\hline This country & 0 & 12.8 & 9.8 \\
\hline Other country & 0 & 68.6 & 45.5 \\
\hline \multicolumn{4}{|c|}{ Time living within community (\%) } \\
\hline Less than 5 years & 0 & 12.6 & 41.2 \\
\hline $6-10$ years & 0 & 23 & 0 \\
\hline $11-15$ years & 0 & 12.6 & 5.9 \\
\hline $16-20$ years & 10 & 14.9 & 17.6 \\
\hline More than 20 years & 90 & 36.8 & 35.3 \\
\hline
\end{tabular}

The SCP farmers had the highest percentage (42.5\%) of farmers with more than 20 years of farming experience.

\section{The institutional arrangements in the SCP decision-making process}

The federal government at ministry level has the power to formulate policies and regulations, although some powers are delegated to state and local government agencies. Management of the seaweed industry at the national level is led by the Ministry of Agriculture and Agro-Based Industry with the Department of Fisheries Malaysia (DOFM) as the responsible agency. The DOFM, which is based in the Federal Territory of Putrajaya, is responsible for governing fisheries, using the Fisheries Act 1985 (Amended 2012) as a legal framework. The Sabah Ministry of Agriculture and Food 
Industry and the SFD are the responsible agencies for managing the seaweed industry at the state level, while the district office (i.e., Semporna) is responsible for managing seaweed projects at the local level.

The federal, state and local levels were all involved in the SCP decision-making process: the federal government was responsible for planning, monitoring, and providing funds to the state government; the state government, through the SFD, selected the sites; while the local community leader selected the SCP participants from within the local communities (SCP Manager KI interview, 06 May 15). The SFD contacted the community leaders, who provided names of local people that were interested in joining the SCP. Ahead of project approval, the SCP committee at the local level (comprising SFD officials and community leaders) visited each village and interviewed all participants to ensure that the participant list was legitimate and contained genuine candidates, i.e., Malaysian citizens employed full-time as seaweed farmers. The finalised SFD participants list was submitted to the federal level for approval. The DOFM (the federal level) then released funding to the SFD to implement the project after NSTC approval.

This study found that $76 \%$ of KI $(n=23)$ were not members of the NSTC and not involved in decision-making for seaweed industry management. However, $100 \%$ felt they were informed of seaweed interventions and knew of at least one seaweed programme implemented in Sabah. Although they were informed about seaweed programmes, more than half were unsure about the impact of the programmes. Overall, $48 \%$ of the KI were involved passively in seaweed industry management, and $71 \%$ had communicated with more than ten organisations in their social network relationships. As shown in Fig. 2a, 65.2\% of KI felt that seaweed farming was very important for the country, particularly coastal communities, whereas $26.1 \%$ and $8.7 \%$ perceived seaweed farming to be important or less important, respectively. However, there were split views within that $65.2 \%$ over whether the government had prioritised seaweed industry management issues less than other government issues (less important: 21.7\%, unimportant: $17.4 \%$, very unimportant: $26.1 \%$ ) (Fig. 2b).

\section{Perceptions of the SCP implementation and its community impact}

\section{User reactions to the $S C P$}

Negative reactions to the SCP were more evident than positive. For instance, positive reactions included the following. A KI claimed that the SCP concept would offer solutions to seaweed problems by increasing efficiency, productivity, and incomes for farmers through the adoption of innovative farming techniques, and the formation of farmer organisations (DOFM KI interview, 14 Jun 15). The community leaders and members agreed to the project as it symbolised high social status as a successful seaweed community. As one SCP leader stated, "the government has chosen our community because we have the most productive seaweed area and we produce good quality seaweed. There are seaweed farmers in other villages on this island, but our community has the most active farmers" (SCP leader GG KI interview, 10 May 15). Similarly, another SCP leader felt that the SCP implementation demonstrated that the government acknowledged the importance of seaweed farmers: "By joining the SCP we felt that the government appreciated us as seaweed farmers and it symbolised that our participation in this activity is important" (SCP leader LB KI interview, 13 Apr 15).

Negative reactions included criticism that while most interview respondents (73.9\%) felt they were informed of the SCP implementation, they were unsure about the programme's impact. They said they were not involved in the seaweed industry management decision-making at a national/federal level, and although the SFD engaged with community leaders and members before the SCP implementation, their views were not taken as part of the planning. Rather,

"The SFD conducted a meeting with the communities in March 2012 to inform them of the SCP and we provided an explanation of the SCP concept and the benefits of this project. We also explained that it will take some time to see the SCP impacts At that time, the government had the funding and we wanted to select individuals to participate in this project and provide them with assistance"

(SCP Manager KI interview, 06 May 15).

Feelings of a lack of participation in the SCP decisionmaking process were strongest in Gelam-gelam. During an SCP farmers' focus group in 2015, the participants claimed that:

"The SFD did not think carefully when they introduced the SCP. The SFD did not consult us before implementation. We only knew about the project when they wanted to build the infrastructure at our village. The system is unsuitable for us. We accepted because it was the governments' project"

(Gelam-gelam SCP farmers" Focus Group, 02 Jun 15).

Moreover, there was confusion over the purpose of the SCP. One KI at the local level stated that "the SCP cooperative was formed as a formality to receive assistance from the government" (SFD Local KI interview, 09 Apr 15). During a focus group in Gelam-gelam in 2015, the SCP participants voiced dissatisfaction that although they belonged to the SCP cooperative the SFD official only used their name to gain government assistance (Gelam-gelam SCP farmers' Focus 
Fig. 2. The perceptions of the importance of; a) seaweed farming to the country; and, b) seaweed industry management issues in comparison to other government priorities
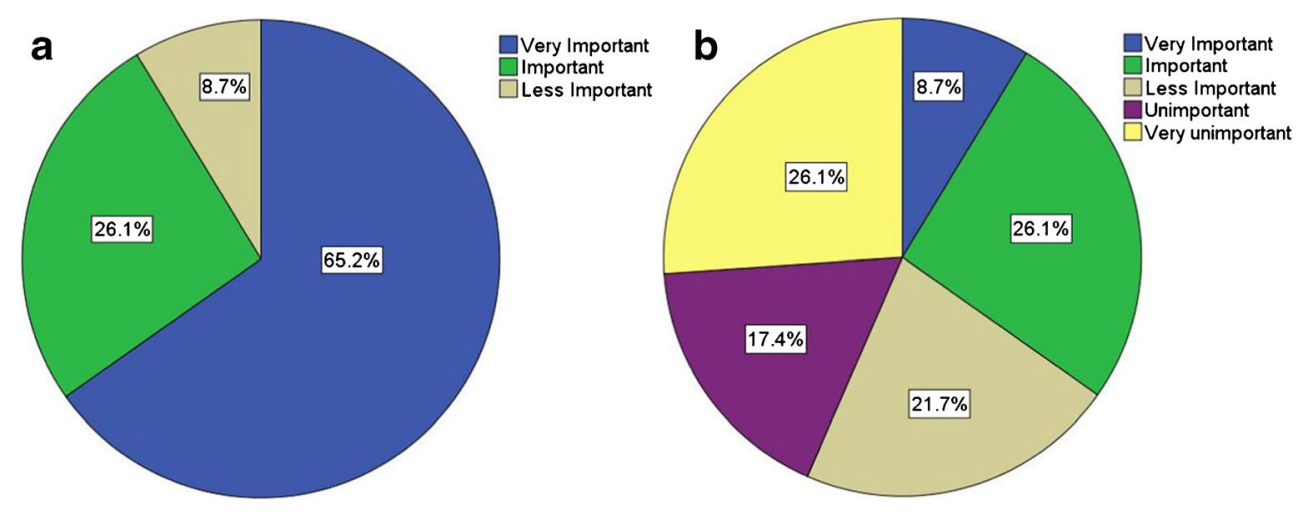

Group, 02 Jun 15). A SAFA manager claimed that the federal level wanted to transform seaweed farming to a commercial scale, but local people felt the seaweed project was another poverty eradication programme (SAFA Manager KI interview, 14 Apr 15).

More serious criticism was voiced that the government failed to choose genuine farmers or companies to participate, and that the SCP project was largely a publicity stunt: "the government's aim for seaweed programmes such as the SCP, the mini estate or seaweed National Key Economic Area (NKEA), are that they are all just for publicity and to look good on paper. The participants they chose might not be genuine players and the government did not know what was happening on the ground and had no idea what will happen to this industry in the future" (Processor LF KI interview, 13 Apr 15). The government rejected this criticism, insisting that it took seriously its responsibilities to rigorously select appropriate farmers for the SCP. The government claimed that not only did it enforce the strict criteria to be met by individual farmers (such as Malaysian citizenship, residency in the local community, full-time seaweed farmer, and entitlement to the farming site), but it also required additional criteria to be met, and the SFD gave a full mandate to community leaders in choosing the SCP participants, because "the villagers only deal with people they know and that is why we can only meet with them through their leader" (SCP Manager KI interview, 06 May 15).

A further source of resentment among the SCP participants was over the subsidised aid given to them by the government. Participants at both sites considered the number of boats provided to be neither sufficient nor practical. Some participants quarrelled over boat usage (LOCAL SFD KI interview, 09 Apr 15), for example, participants complained that 'the boat given is not enough and we have to take turns. If everybody wants to go to the farm we will face problems' (Lok Butun SCP farmers' Focus Group, 03 Jun 15). Lack of boat ownership/access is a major constraint in seaweed farming in Malaysia. The SCP farmers perceived that they could not farm without a boat unless they borrow from relatives or friends (Gelam-gelam SCP farmers' Focus Group, 02
Jun 15). This study found that $42.5 \%$ of the SCP farmers did not own a boat, whereas all (100\%) of non-SCP and SAFA farmers owned at least one boat.

\section{The impact of the SCP in increasing seaweed production and farmers' income}

The SFD provided both individual and collective farming inputs to the SCP participants (SCP Manager KI interview, 06 May 15). Individual assistance ensured that each participant received $600 \mathrm{~kg}$ of seedlings, a free assessment for seaweed farm certification, and $50 \mathrm{EFL}$ (Figs 3 and 4). Excluding the cost of farm certification, the government estimated the initial cost per individual to be MYR 30,000 (US\$ 9870). Collective assistance ensured that the government provided two fibreglass boats, eight tying tables and built drying platforms for each SCP site (Figs 3 and 4), costing approximately MYR 1.0 million (US\$ 330,000) per site. In return, the participants had to utilise the innovations as a condition of the project.

The SFD estimated the seaweed production per cycle for $50 \mathrm{EFL}$ in a two-hectare farming area to be one tonne dry weight per ha per cycle, i.e., six tonnes dry weight per year (based on three cycles per year). KI and seaweed farmers reported that a production cycle lasted seven to eight weeks, therefore the theoretical maximum number of cycles per year is eight. However, production is seasonally affected (Stakeholders' Focus Group, 04 Jun 15) so that in reality most farmers could only farm between two and six cycles depending on site. The Lok Butun SCP participants experienced two to four cycles per year while Gelam-gelam SCP participants, SAFA farmers in Mata Pahi/Melanta Kobal, and migrant farmers in Sebangkat and Palang-palang experienced two to six cycles; whereas migrant farmers in Patuit and Sangaban experienced three to eight cycles. Figure 5 shows the seaweed productivity from 144 farmers. All SCP farmers produced less than five tonnes of dried seaweed per year. However, the majority of migrant (60.9\%) and SAFA $(94.1 \%)$ farmers produced at least six tonnes per year. 
Fig. 3. Individual and collective farming inputs provided to the SCP participants: a) Eco-friendly longlines installed at the SCP site at Lok Butun, Bum-bum Island; and, b) the SCP drying platform at Gelam-gelam, Bum-bum Island

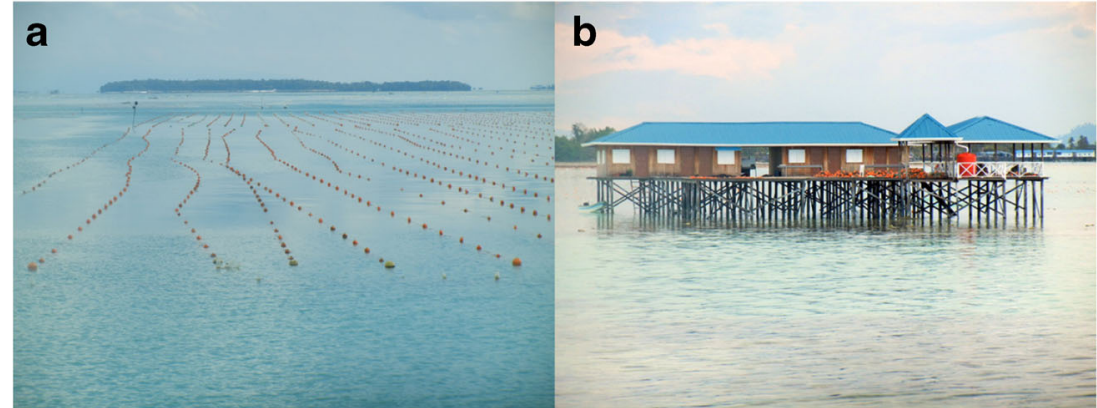

In 2008, the Sabah state government introduced the Projek Mini Estet Sejahtera (MESEJ) Rumpai Laut (Prosperous Mini State Seaweed Project) to the Bum-bum island community as an initiative to reduce poverty. The same participants, or their children or grandchildren, were chosen to participate in the SCP. Under the MESEJ programme, the Lok Butun participants were designated a farming area based on traditional customs or inheritance from parents. According to a community leader, the older generations who started seaweed farming in the 1980s chose farming sites close to their houses. When the SFD selected Lok Butun as an SCP site the Semporna District Office declined to establish the SCP at the MESEJ programme sites, but instructed the SFD to build the SCP infrastructure in designated Seaweed Aquaculture Industry
Fig. 4. Selected technological interventions provided as part of the SCP: a) used plastic bottles for flotation were replaced with polyfloats; b) raffia tie-tie were replaced with polyethylene; c) a concrete/cement anchoring system replaced the conventional anchor rope approach (the anchor rope was often tied to live coral); and d) dugout canoes were replaced with fibreglass boats and seedling tying was done from a tying table at the SCP drying platform

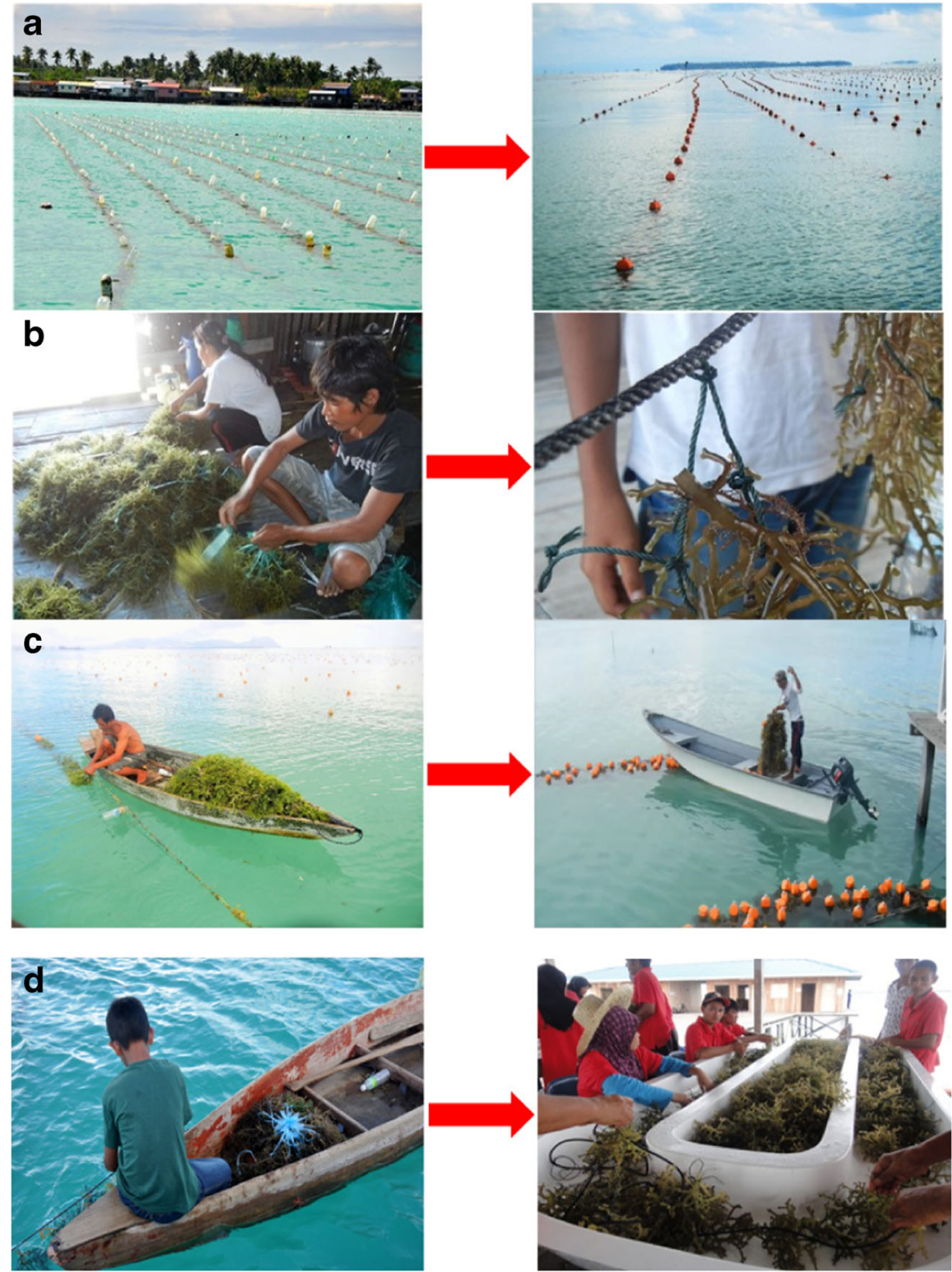




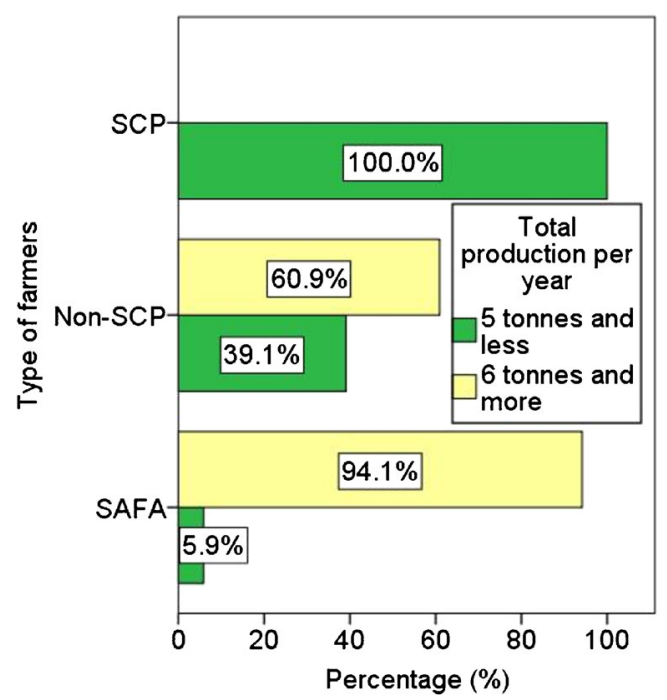

Fig. 5. The proportion of farmers (SCP, non-SCP, and SAFA) achieving productivity targets of six tonnes dry weight per year

Zones (SAIZ) (tracts of sea that had been gazetted by the government for seaweed aquaculture activities only). When the villagers were selected to participate in the SCP, they were allocated a new farming area within the SAIZ, which was distant from their houses. The Lok Butun farmers could choose to plant seaweed at the MESEJ or SCP sites, of which $52 \%$ farmed two sites using differing farming systems - the conventional longlines system at the MESEJ sites $(210 \mathrm{~m}$ ropes with raffia strings as tie-tie and used plastic bottles as buoys); and the SCP system (100 $\mathrm{m}$ ropes with double PE strings as tie-tie with poly-floats as buoys) at the SCP sites. Based on the survey, $16 \%$ farmed the MESEJ sites only, a decision based on four main reasons: a preference for raffia tie-tie (although non-SCP farmers eventually changed from raffia to PE tie-tie as they became aware of seaweed quality implications); the farm location was nearer; a perception that the SCP site was problematic due to seaweed predation; and that one person could manage the conventional farming system whereas at least two people were needed to work the SCP system. As mentioned by the SCP participants, "if we were given a choice, we will choose raffia tie-tie. Seaweed biomass is heavier if we use raffia tie-tie...the location of the drying platform is far from our house. It's not practical" (Lok Butun SCP farmers' Focus Group, 03 Jun 15). In contrast, all Gelamgelam SCP farmers allowed their previous farming systems to be replaced by the SCP system (SCP Leader GG KI interview, 10 May 15). Previously, they were not involved with the MESEJ programme, therefore their sites had no constraints on other forms of seaweed intervention.

Although the level of abject poverty in Malaysia decreased from $49.3 \%$ in 1970 to $0.6 \%$ in 2014 , Sabah remains a relatively poor state (Hatta and Ali 2013), and Semporna one of its poorest districts:
"Seaweed farming has been used as a poverty alleviation programme for districts facing poverty issues, and Semporna district is one of poorest in Sabah. Most of the poor people are fishermen and from coastal communities" (Local SFD KI interview, 09 Apr 15).

According to the SCP manager, all of the SCP farmers selected by the community leaders were on the poverty list, but had not previously received any government aid. He said "we get the list from the e-kasih list (poverty list) provided by the district office. None of the SCP participants had received any government welfare schemes except individual aids". However, the HS found that $35.0 \%$ of the SCP farmers had obtained support through the governments' welfare house scheme through the MESEJ project, which contradicts the claim made by the SCP manager. Nevertheless, the SCP farmers were poorer than the non-SCP farmers. For example, only $40.0 \%$ of the SCP farmers owned their houses compared with $77.9 \%$ of nonSCP farmers and only $6.7 \%$ lived in welfare houses (mainly from the SAFA community, since other nonSCP farmers, particularly migrants, were ineligible for government assistance). Therefore, the SCP project did target poorer members of the community, with the exception of migrants.

Total SCP production for each farmer was estimated at $6.0 \mathrm{t}$ dry weight per year with an annual income of MYR 14,000 (US\$ 4600) if the price per kg dry weight was MYR 2.50 (US\$ 0.82). However, SCP farmers did not see the SCP project as either alleviating their poverty or increasing their income. The HS showed that the actual production was less than $5.0 \mathrm{t}$ dry weight per year per SCP farmer (Fig. 6), and the actual annual income was less than MYR 14,000 (US\$ 4600) per SCP farmer. This is mainly due to the poor market price for seaweed. During the SCP farmers' focus group in 2015, the participants agreed that "seaweed farming is not a lucrative business" (Gelam-gelam SCP farmers' Focus Group, 02 Jun 15). The low seaweed price was a strong disincentive for the SCP participants to focus solely on seaweed farming. As mentioned by the KI, "one of the seaweed farm owners met with me last night and expressed his worries for this industry due to the low price. At the moment, the guy bought a fishing net and gave it to his workers because of seaweed farming being slow. The workers need to do other things to get income for them and their employer" (SFD Official KI interview, 28 May 15). One reason for the low market price for seaweed was the restricted marketing system based on intermediaries (buyers). All of the SCP participants in both villages agreed that the only market source for their produce was through intermediaries. The majority $(82.5 \%)$ of participants chose 


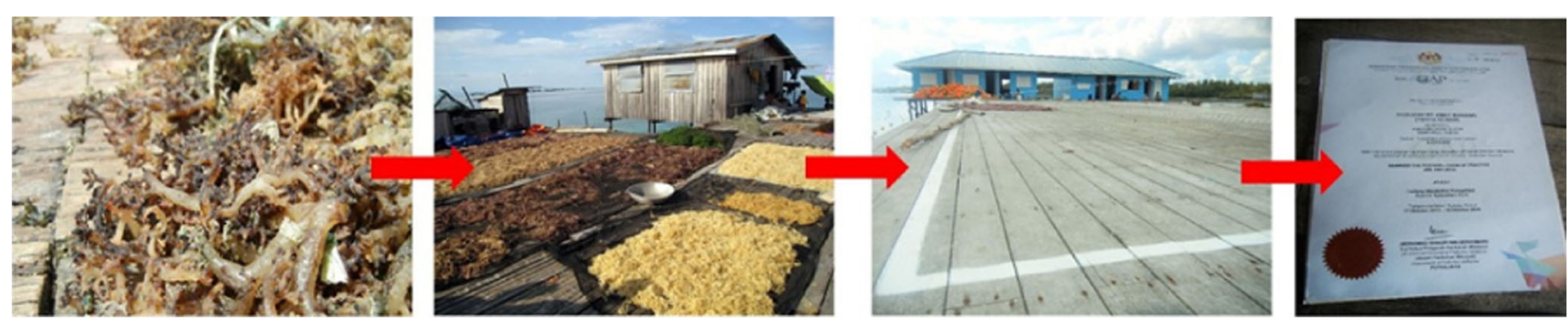

Fig. 6. Improving seaweed quality and achieving MyGAP certification by encouraging the SCP farmers to improve post-harvest handling by switching from drying seaweed at their house to the SCP drying platform

intermediaries, while $15.0 \%$ and $2.5 \%$ chose good friends or relatives (who impose no quality control) as their buyers, respectively. One of the reasons that discouraged most SCP participants from selling seaweed directly to the carrageenan processor or to exporters for a better price was their lack of seaweed marketing knowledge (82.5\% of total participants). Even though some (17.5\%) knew about seaweed marketing, especially white seaweed or rumpai putih for direct consumption, they could not sell directly to the end users because of poor marketing networks (37.5\% agreed, $40 \%$ unsure and $22.5 \%$ disagreed) and poor entrepreneurship (47.5\% agreed, $30 \%$ unsure and 22.5 disagreed) even after they had joined the SCP.

This study found that $87.5 \%$ of the SCP farmers earned less than US\$ 10 per day per farmer from seaweed farming, which is below the national Poverty Line Income (PLI) (Hatta and Ali 2013), while only $43.3 \%$ of non-SCP farmers earned less than US $\$ 10.0$ per day per farmer. Only 8 and $20 \%$ of the SCP farmers in Lok Butun and Gelam-gelam, respectively, earned more than the national PLI level from seaweed farming. By contrast, seaweed farming alleviated the poverty of most of the non-SCP migrant (55.2\%) and SAFA farmers $(64.7 \%)$. Therefore on balance, the SCP has not alleviated poverty for most participants: we found the same results as the SFD annual report which stated that the SCP participants' incomes for 2013 and 2014 were less than US\$ 10 per day per farmer (Sabah Fisheries Department, unpublished data). These findings mean the cluster project has not met its aim of increasing household income to more than US\$ 10 per day per farmer. The SCP participants who perceived that their income had not improved felt that five factors were responsible - the government has not provided enough seedlings for them; seasonal changes; diseases; predation problems; and price fluctuations. However, they felt that the assistance they received from the government had reduced their operating costs on farming inputs and replaced broken farming ropes and buoys.

\section{The impact of technical innovations to improve seaweed} quality and farming efficiency

Malaysia has laid down seaweed standards on seaweed cultivation, dried seaweed and semi-refined carrageenan. The price of dried seaweed is determined by using dried seaweed from carrageenophytes to meet Specification (MS 2528:2013) standard. However, the certification scheme is voluntary, and farmers and processors can choose whether they want to participate or not. As mentioned by MARDI RO KI interview, 09 Jun 15: "The MyGAP seaweed certification scheme helps the farmers in terms of their hygienic practices but does not increase seaweed prices". Even though the seaweed certification scheme has been implemented in Malaysia, this only applies to the local farmers and of those, is limited to the SCP farmers in Lok Butun. The government perceived that the Lok Butun SCP farmers were ready to participate as they have farming facilities that would comply with the certification scheme. It therefore seems that MyGAP certification is limited to farmers who operate from the government's facilities i.e., drying platforms. One KI commented that "we have to upgrade the infrastructure provided by the federal government to get MyGAP certification. With MyGAP, seaweed produced in SCP Lok Butun can easily be exported because of hygiene and being safe to eat" (SCP Manager KI interview, 06 May 15). But farmers were not taking full advantage of certification: "The SCP farmers can demand a higher price if their seaweed is certified; however, at the moment they have not exported their produce and follow the normal market prices" (SCP Manager KI interview, 06 may 15). The farmers perceived that seaweed prices remained the same regardless of whether they complied with the certification requirements because the intermediaries dictate the price, and they are the only source of marketing (Stakeholders' Focus Group, 04 Jun 15).

Technological interventions were viewed as necessary if the SCP was to increase productivity; however, the farmers' views on the practicality, economic sustainability, and environmental and social acceptability of the interventions revealed some resistance to their adoption - which may have hindered the programme's success. The SFD provided both 
individual and collective farming inputs to the selected participants (SCP Manager KI interview, 06 May 15) (Fig. 6). The eight SCP technological interventions (PE tie-tie, poly-floats, detachable eco-friendly long lines (EFL), concrete anchoring systems, seedling tying tables, wooden drying platforms, fibreglass boats, and the seaweed certification programme received a wide variety of responses. Among the criticisms of government assistance was that while each EFL was $100 \mathrm{~m}$ long and could be planted with $120 \mathrm{~kg}$ wet weight of seedling, equating to each participant requiring $6.0 \mathrm{t}$ of seedlings for 50 EFL, the government only provided $600 \mathrm{~kg}$ seedlings or $10 \%$ of the total seedlings required by each participant to start their farming activity. The SFD said that participants had either to produce their own future seedlings using vegetative propagation from the given $600 \mathrm{~kg}$, or to obtain future seedlings by purchasing them from other farmers. But participants complained that vegetative propagation took a long time and was uncertain, and they could not afford to buy seedlings from other farmers. The EFL were simply regarded as equivalent to standard PE ropes without any improvement on current practises, apart from a shortened rope length. In contrast, the SCP participants who chose the SCP site preferred - in terms of usefulness and practicality - the poly-float buoys, followed by the EFL, the seaweed certification scheme, the boats, the anchoring system, the drying platform, the PE tie-tie, with the tying table the least liked. The design and colour of the polyfloats attracted visitors to the villages; this 'SCP identity' had a positive perception. The Lok Butun SCP community held mixed views of the farming efficiency. As mentioned by their leader:

"We have two groups; $A$ and B. Each group was allocated with one drying platform by the government. The difference between group $A$ and $B$ is the set-up of farming sites. Group A use the same site as their previous farms before they joined the SCP while group B use the new farming sites that were allocated by the Sabah Fisheries Department in the SAIZ area. Group A and $B$ use either farming systems either $S C P$-only or in combination with conventional systems. The EFL uses double tie-tie points for seedlings while the conventional system only uses one tie-tie. I think the EFL system optimised the farming site because one line of EFL is equivalent to three lines of the conventional method" (SCP Leader LB KI interview, 13 Apr 15).

The SCP participants in Gelam-gelam had to farm at one site only. All of the Gelam-gelam SCP participants perceived the farming area was optimised with the installation of the SCP farming systems on two hectare areas, whereas $52 \%$ of the Lok Butun SCP participants felt that their farming area was optimised. Despite the higher percentage in Gelamgelam, $80 \%$ of respondents felt that the production output was the same as with the previous farming system. The majority of the SCP participants (more than $90 \%$ ) in both villages felt that seaweed quality and labour usage were the same as previously (Table 3).

\section{SCP initiatives to reduce environmental impacts}

The survey revealed two perspectives on environmental impacts; one focusing on plastics pollution and the other on water quality. The SCP farming system uses EFL as its main feature, which uses neither raffia tie-tie nor plastic bottles. The EFL replaces the conventional hanging longlines with the intention that it would reduce the environmental impact of seaweed farming (Fig. 6). The hanging longlines system used recycled plastic bottles as buoys and raffia tie-tie to tie seaweed to the main farming ropes; however, the SFD regarded these as polluting as the farmers discarded broken bottles and raffia tie-tie into the sea. The MyGAP seaweed certification scheme prohibits any pollution from farming activities, and the SFA viewed the EFL as the best approach to fulfil the requirement (Fig. 6) as described by the KI:

"The government have improved the farming system by introducing environmentally friendly methods in the SCP. If you visit the farm you can see the differences between the SCP and individual farmers. Most of the individual farmers still use empty bottles as floats which polluted the environment. The SCP participants do not pollute the environment because they use poly-floats that are environmentally friendly. Also, the SFD monitor

Table 3. Percent distribution of perceptions at two SCP communities of increased seaweed production, successful optimisation of the farming areas, and improved seaweed quality and farming efficiency

\begin{tabular}{ll}
\hline Indicators & SCP Participants \\
& Lok Butun $(n=25) \quad$ Gelam-gelam $(n=15)$
\end{tabular}

a) Perception of optimising farming area by using the SCP farming systems

i. Optimised $\quad 48 \% \quad 100 \%$

ii. Not optimised $\quad 52 \% \quad 0 \%$

b) Perception of production by using the SCP farming systems

i. Better $\quad 0 \% \quad 20 \%$

ii. Same $\quad 100 \% \quad 80 \%$

c) Perception of seaweed quality produced by using the SCP farming systems

$\begin{array}{lll}\text { i. Better } \quad 4 \% & 6.7 \%\end{array}$

ii. Same $\quad 96 \% \quad 93.3 \%$

d) Perception of labour usage by using the SCP farming systems

i. Reduced labour $\quad 4 \% \quad 0 \%$

ii. Same $\quad 96 \% \quad 100 \%$

$\begin{array}{lll}\text { Total } & 100 \% & 100 \%\end{array}$ 
the SCP using the Malaysia Good Agriculture Practices (MyGAP) approach that gives certification to this system" (PEMANDU KI interview, 15 Jun 15).

His opinion was shared by the SCP leader by saying this: "I think the difference between the traditional and the SCP system is from the environmental aspect because the SCP uses an eco-friendly long line system. When we obtained the seaweed MESEJ poverty alleviation project in 1996, the development agents complained about pollution from our farming activities, for instance, pollution from the plastic bottles that we use as a float. But we don't have a choice because this system has been practiced since the 1990s and the government is the one whom introduced it to us" (SCP Leader LB KI interview, 13 Apr 15).

Paradoxically, the introduction of EFL caused an immediate increase in pollution. Prior to the introduction of the SCP, the communities collected all the good condition plastic bottles that floated under their houses to be used as spares for their existing floats. Anecdotal evidence showed that this practice was abandoned with the advent of the EFL. The community leader raised his concerns on this matter by saying that "nowadays, the environmental issue is severe because of pollution from the community. You now see a lot of waste, particularly used plastic bottles in the sea during the north east season. They do not care about it anymore" (Community Leader LB KI interview, 16 Apr 15). When questioned on the environmental impacts of seaweed farming, $97.9 \%$ thought that it does not contribute to marine pollution. KI also did not perceive a risk of environmental pollution in seaweed farming areas.

The success of seaweed farming is closely associated with the physiochemical parameters of seawater such as temperature, $\mathrm{pH}$, salinity and turbidity. According to the SCP leader:

\begin{abstract}
"Another issue was seaweed growth not being the same as when I started this activity in the year 2000. I think this is related to pollution caused by the increasing number of houses and people in the community. I used to harvest 2-3 kg of seaweed per plant but nowadays the most I can get is $1.5 \mathrm{~kg}$, a big difference. Last time the seawater colour was blue and nowadays it is green. The water quality is poor and is causing the spread of ice-ice disease in the seaweed. That is why the seaweed size is smaller nowadays" (SCP Leader LB KI interview, 13 Apr 15).
\end{abstract}

Whereas there is no evidence that the SCP has directly impacted seawater quality, should seaweed farming continue to grow and attract additional practitioners from outside the local communities, this may exacerbate any decline in water quality with knock-on consequences for seaweed production.

\section{Social network strength}

The migrant and SAFA farmers' social cohesion was strong and they would help each other rather than rely on the government to solve problems within their communities. Moreover, both communities believed they have strong and respected leadership within the communities. In contrast, the SCP farmers did not think highly of local leadership, had low social cohesion, and relied on the government to solve problems (Fig. 7). This study found that there was resentment between the SCP farmers because of dissatisfaction with farmers who were selected despite not being seaweed farmers and not owning seaweed farms at the Gelam-gelam SCP site. One KI said, "they do not farm seaweed and kept the inputs given by the government at their home" (SCP Leader GG KI interview, 10 May 15). This KI said that the previous SCP leader had chosen farmers whom he knew were neither seaweed farmers nor owners of farming sites. This created resentment among the SCP farmers in east Gelam-gelam who were genuine farmers and had to give up some of their farming areas to the new SCP farmers in west Gelam-gelam, who were not genuine farmers:

\begin{abstract}
"Most of the farmers in west Gelam-gelam are new farmers and they do not own the farm, including the previous leader. Meanwhile, all the farmers in east Gelam-gelam are seaweed farmers and owned seaweed farms before joining the SCP. They had to give their existing farming areas to the SFD so that they can manage and divide to other farmers" (SCP Leader GG KI interview, 10 May 15).
\end{abstract}

There was evidence of poor governance principles which can impact the level of social cohesion as the results identified although most of the SCP farmers in Lok Butun have family relationships with each other they did not discuss their problems openly and did not interact with their leader to solve the problems within the communities.

\section{Discussion}

The study has identified five main issues that may explain the success or otherwise of the SCP programme; relations between indigenous and migrant farmers; stakeholder participation; human capital; livelihood strategies; and local leadership. 


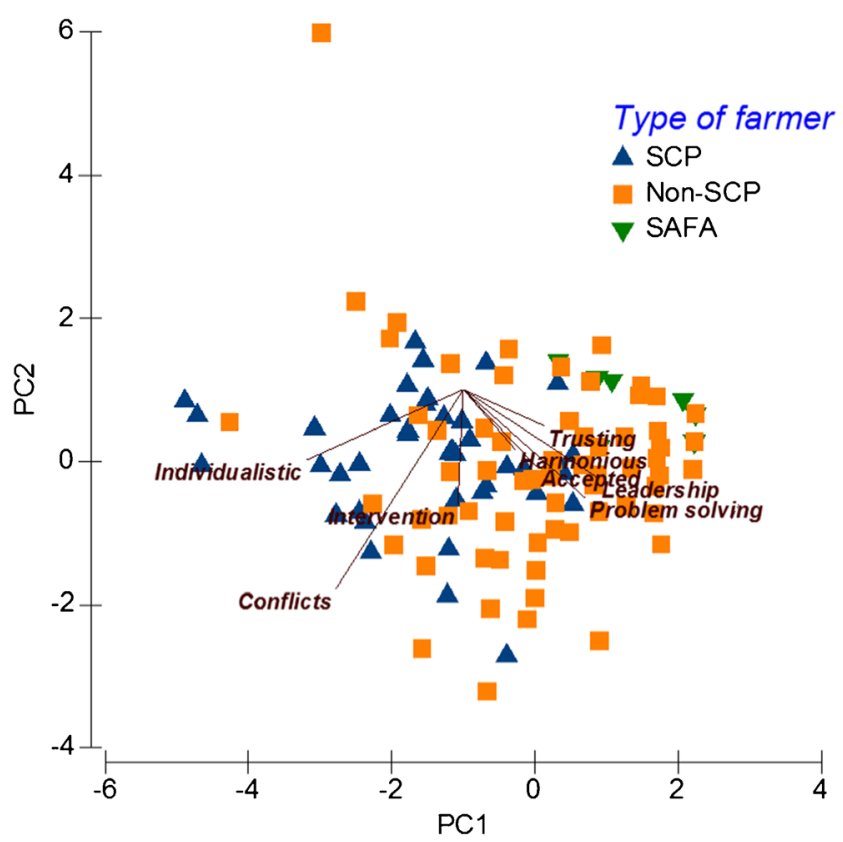

Fig. 7. Principal component analysis of the social network strength within the seaweed communities (SCP, non-SCP, and SAFA) in Semporna

\section{Relationship between indigenous and migrant farmers}

The tense relationship between indigenous and migrant seaweed farmers is in part linked to the split between female and male farmers. Local community involvement in seaweed farming has broadened through growing female participation, although this remains low as the women lack seafaring skills (Cooke 2004). The longlines system requires deep water (2 to $5 \mathrm{~m}$ ), necessitating the use of boats. As outboard engines are costly, farmers use dugout canoes (bogo-bogo) for farm access, which are difficult to handle without the necessary seafarer skills. Also, using the conventional longlines system a farmer usually works under the hot sun when tying seedlings, whereas the women prefer to assist from home (Kronen et al. 2010). In contrast, seaweed farming in Zanzibar and India is female dominated as they received assistance through credit services and skills training (Valderrama et al. 2013; Periyasamy et al. 2014). Also, the farming system used in Zanzibar is fixed-off bottom in shallow water, which avoids boat use (Msuya 2013). In Semporna, the female SCP participants were either widows or divorcees, preferring to hire labour (mostly from migrant communities) rather than farm themselves.

The Moro conflict in the southern Philippines forced more than 50,000 people to migrate to Sabah in the 1970s (UNHCR 2014). In the late 1980s, the Malaysian government divided the Filipino migrants into three categories; illegal migrants, war refugees, and economic migrants (Kassim 2009). Seaweed farming became a safety net for migrant communities living in pondohan stilt huts, not only because they felt safe living at sea but because the authorities did not obstruct their way of life or their farming activities. Although official data on the number of migrant farmers are unavailable, KI claimed that they dominate the industry, generating more than $50 \%$ of total national seaweed production. The migrant farmers also had strong leaders (usually a respected person holding Malaysian citizenship), who deal with the indigenous people and authorities if required. The pondohan migrant communities have strong social cohesion, into which the leaders will not admit random immigrants as they are aware of governmental concerns surrounding immigrant issues. Migrants generally do not commit crimes or create social problems as they do not want to attract the attention of the authorities. Moreover, social capital was high among migrant communities, whereas it was low among the indigenous SCP farmers who were often involved in disputes over the project. Nevertheless, migrants were blamed for the lack of government support for the seaweed industry, as the industry is considered a threat to national security as it attracts more migrants from the southern Philippines. Consequently, the government is reluctant to grant sea tenure to migrants, or permit them to participate in the SCP, despite their obvious value as seaweed producers.

\section{Stakeholder participation}

There was disconnect between farmers and government officials. Farmers felt estranged from the decision-making process concerning community development programmes, and perceived the government to have absolute decision-making power. Government officials confirmed that farmers were not involved with decision-making at the national level, but were involved to some extent at state and local levels. Respondents argued that before the implementation of seaweed projects, the government should engage with all stakeholders, including farmers, buyers, processors, officials and NGOs; inclusiveness being an effective approach to gather information and input from stakeholders (Gray 2005; Lockwood et al. 2010). Interviewees complained that poor stakeholder participation leads to feelings of marginalisation from decision-making. Embedding local input and knowledge in decision-making would also produce a better understanding of socio-ecological systems (Reed 2008).

\section{Human capital}

Interviewees criticised the government for failing to provide the SCP farmers with entrepreneurial skills that would have allowed them to make the transformation from individual small-scale producers to commercial-scale production. The SCP farmers perceived that they possessed neither the economic nor human capital to manage their farms. They claimed that the seedlings provided by the government were 
insufficient so most of the farming lines were left empty, and that they lacked training in technical skills to make use of the new technology. Seaweed farming is a simple activity, using cheap and recycled materials to establish the farm and individuals can learn farming skills by themselves or through observation. However, work experience using the same practises does not necessarily result in higher productivity, unless the individual switches to new technology (Hanna et al. 2014). All seaweed intervention projects are about introducing new innovations, but farmers need training in such skills (Vredegoor and Pennink 2013).

The SCP farmers also complained that they were not given guidance on marketing strategies. Seaweed farming is a risky financial activity, not least because the seaweed price constantly fluctuates and often seaweed farmers receive very low prices from the buyers who come to their islands or villages. Seaweed farmers usually do not sell directly to the processors because they lack marketing information: they believed that processors hire their own agents or buyers to obtain specific quantities of seaweed. The government do not assist farmers to develop marketing skills. Carrageenan processors mentioned that when they met with government agencies to discuss seaweed marketing, they perceived the agencies do not know how to deal with it as the government lacks the capability of managing the seaweed industry and its marketing system. Although several KI perceived that the seaweed industry will develop and expand because of government interventions and continued strong global demand from the processed food industry, respondents identified many problems with marketing. For example, seaweed buyers said that if the government wanted them to export legally, they should facilitate the export procedure and build a port and appoint an export agent based in Semporna rather than in Tawau as it will be costly for them to go to Tawau for documentation preparation. Also, most seaweed buyers did not know how to register or use online marketing services. Despite this, stakeholders believed that the industry will develop and expand due to government interventions and the continued strong global demand for carrageenan.

\section{Livelihood strategies}

Sabah is one of the poorest Malaysian states with a GDP of MYR 18,603 (US\$5673) per capita in 2013, compared with the national GDP per capita of MYR 33,000 (US\$10,064) (DOFM 2013; DOS 2013). The Sabah fishing communities (especially in Semporna) are among the poorest in Malaysia (Solaymani and Kari 2014) with small-scale fishers portrayed as "the poorest of the poor" (Allison and Ellis 2001). Part of the attraction of seaweed farming as a poverty reduction strategy is that it is a household enterprise involving farmer's wives and family members (Cooke 2004). However, farmers in Semporna perceived seaweed farming to be a low income source which drove a lack of interest among coastal communities. Seaweed farming is not perceived as the main livelihood, rather fishing remains the main income source of those who make their living from the sea (Hill et al. 2012).

\section{Local leadership}

Local leaders provide a vital link between the community members, industry and government. In addition, strong local leadership can increase social cohesion among community members (Bodin and Crona 2008; Gutiérrez et al. 2011). The SCP leader has an important role as s/he is responsible for choosing and managing the SCP participants. KI drew attention to deficiencies of leadership in their SCP projects, claiming a lack of trust. For instance, ten Lok Butun SCP participants quit the project as they thought the leader was corrupt. They also perceived that the leader was not fulfilling his promise of the project's development: for example, he resided in the neighbouring village, did not monitor the project unless there was a visit from government officials or politicians, and was head of the youth wing of the local political party, which compromised his independence.

\section{Conclusions and recommendations}

This research found there to be conflicting views over the outcomes of the SCP in Semporna. Negative perceptions included low take-up rates by indigenous people, poor stakeholder participation in decision-making processes, economic vulnerability of seaweed farmers, a complex marketing system, low social cohesion among beneficiaries, and limited acceptance of new technologies. Positive perceptions included a recognition that the SCP confers high social status upon a community, reduces operating costs of seaweed production, and facilitates the production of certified seaweed. Tellingly, the non-SCP farmers were more successful than the SCP participants in performing seaweed farming activities. This study concludes by making five recommendations for improving the SCP.

Firstly, the government should increase and promote the participation of indigenous people in seaweed farming, particularly females and youths. Although, the current seaweed projects were awarded to local people, their engagement was poor and they perceived seaweed farming as an unpredictable source of income. Secondly, the government should confer legal status upon the existing migrant farmers rather than ignore their existence. However, the government has to set the criteria for the selection and make sure the authenticity of the documents, i.e., legal status as the war refugees. Additionally, this effort will provide the government with an accurate view 
of the current status of migrant farmers in Malaysia, which eventually will reinforce national security. Thirdly, the local seaweed cooperative organisations should be strengthened so that these organisations could provide the platform for farmers, buyers and processors to address seaweed related issues. The cooperatives could also provide services and become a business network for members. Fourth, the government should teach entrepreneurship skills to farmers so that they may negotiate with buyers and find other market outlets, thus making farmers more independent. Finally, stakeholders should be fully integrated into decision-making processes, thereby tackling issues based on local needs. Such steps could transform the prospects for seaweed production in Malaysia.

Acknowledgements This work was funded by the Government of Malaysia and Newcastle University, UK. The authors would like to thank the Economic Planning Unit, Prime Minister's Department Malaysia, Department of Fisheries Malaysia and Sabah Fisheries Department for granting permission to conduct this fieldwork. Thanks are due to the seaweed communities in Semporna, community leaders, government officials, NGOs, carrageenan processors and villagers in general for their kindness, cooperation and hospitality which made our work much easier. We would also like to thank Dr. James Alin, Ms. Nazmahwati Walli and Mr. Mizpal Ali of Universiti Malaysia Sabah (UMS) for providing insight and assistance during fieldwork. Also, Mr. Masri Bangkoka of Gelamgelam village for assisting with community assimilation. Any shortcomings of the paper belong to the authors.

Open Access This article is distributed under the terms of the Creative Commons Attribution 4.0 International License (http:// creativecommons.org/licenses/by/4.0/), which permits unrestricted use, distribution, and reproduction in any medium, provided you give appropriate credit to the original author(s) and the source, provide a link to the Creative Commons license, and indicate if changes were made.

\section{References}

Allerton C (2014) Statelessness and the lives of the children of migrants in Sabah, East Malaysia. Tilburg Law Rev: J Int European Law 19: 26-34

Allison EH, Ellis F (2001) The livelihoods approach and management of small-scale fisheries. Mar Policy 25:377-388

Bodin Ö, Crona BI (2008) Management of natural resources at the community level: exploring the role of social capital and leadership in a rural fishing community. World Dev 36:2763-2779

Cooke MF (2004) Symbolic and social dimensions in the economic production of seaweed. Asia Pac Viewp 45:387-400

Dalli ASA (1988) Seaweed Farming in East Malaysia. In: ASEAN/ UNDP/FAO Regional Small-scale Coastal Fisheries Development Project, RAS/84/016.

DOFM (2013) Portal Rasmi Jabatan Perikanan, Department of Fisheries Malaysia, http://www.dof.gov.my/index.php/pages/view/1948.
DOS (2010) Population distribution and basic demographic Characteriestics Putrajaya. Report of the Department of Statistics, Malaysia

DOS (2013) Gross domestic product (GDP) by state, 2013. Putrajaya. Report of the Department of Statistics, Malaysia

Gray TS (2005) Theorising about participatory fisheries governance. In: Gray TS (ed) Participation in fisheries governance. Springer, Netherlands, pp. 1-25

Gutiérrez NL, Hilborn R, Defeo O (2011) Leadership, social capital and incentives promote successful fisheries. Nature 470:386-389

Hanna R, Mullainathan S, Schwartzstein J (2014) Learning through noticing: theory and evidence from a field experiment. Q J Econ 129: $1311-1353$

Hatta ZA, Ali I (2013) Poverty reduction policies in Malaysia: trends, strategies and challenges. Asian Cult Hist 5:48-56

Hill NA, Rowcliffe JM, Koldewey HJ, Milner-Gulland EJ (2012) The interaction between seaweed farming as an alternative occupation and fisher numbers in the Central Philippines. Conserv Biol 26:324 334

Hurtado AQ, Montaño MNE, Martinez-Goss MR (2012) Commercial production of carrageenophytes in the Philippines: ensuring longterm sustainability for the industry. J Appl Phycol 25:733-742

Kassim A (2009) Filipino refugees in Sabah: state responses, public stereotypes and the dilemma over their future. Southeast Asian Stud 47:52-88

Kronen $\mathrm{M}$ et al (2010) Gender and seaweed farming on Wagina Island, Choiseul Province in Solomon Islands. SPC Women Fish Info Bull 21:3-10

Lockwood M, Davidson J, Curtis A, Stratford E, Griffith R (2010) Governance principles for natural resource management. Soc Nat Resour 23:986-1001

Msuya FE (2013) Social and economic dimensions of carrageenan seaweed farming. FAO Fisheries and Aquaculture Technical Paper 580: 115-146

Periyasamy C, Anantharaman P, Balasubramanian T (2014) Social upliftment of coastal fisher women through seaweed (Kappaphycus alvarezii (Doty) Doty) farming in Tamil Nadu, India. J Appl Phycol 26:775-781

Razali DDE, Bahron A, Alin JM (2015) Sustaining seaweed farming in Malaysia. Int J Bus Manag 3:201-205

Reed MS (2008) Stakeholder participation for environmental management: a literature review. Biol Conserv 141:2417-2431

Ryan GW, Bernard HR (2003) Techniques to identify themes. Field Meth 15:85-109

Sade A, Ali I, Mohd Ariff MR (2006) The seaweed industry in Sabah East Malaysia. Jati 11:97-107

Solaymani S, Kari F (2014) Poverty evaluation in the Malaysian fishery community. Ocean Coastal Manag 95:165-175

Thurstone LL (1928) Attitudes can be measured. Am J Sociol 33:529-554

UNHCR (2014) Refugee Factsheet. United Nations High Commissioner for Refugees, Kuala Lumpur. http://www.unhcr.org/56167f6b6.pdf

Valderrama D, Cai J, Hishamunda N, Ridler N (2013) Social and economic dimensions of carrageenan seaweed farming. FAO Fisheries and Aquaculture Technical Paper, vol 580. Rome

Vredegoor MTJ, Pennink BJW (2013) Including capabilities of local actors in regional economic development: empirical results of local seaweed industries in Sulawesi. South East Asian J Manag 7:61-88 